\title{
Analisis Sektor-Sektor Ekonomi Terhadap Penerimaan Daerah Kabupaten Wajo
}

\author{
Bunaya $^{1^{*} \text {, Chalid Imran Musa }}{ }^{2}$, Rahmatullah ${ }^{3}$ \\ ${ }^{1}$ Pendidikan Ilmu Sosial, Pascasarjana Universitas Negeri Makassar \\ Email: naya1509.naya@gmail.com \\ ${ }^{2}$ Pendidikan Ekonomi, Universitas Negeri Makassar \\ Email: imranmusa1962@gmail.com \\ ${ }^{3}$ Pendidikan Ekonomi, Universitas Negeri makassar \\ Email:rahmatullah@unm.ac.id \\ *Corresponding author
}

\begin{abstract}
This study aims to find out the basic economic sector, strategic economic sectors and the potential to be developed as supporting regional revenues in Wajo District. The study was descriptive quantitative research which employed gross regional domestic product data and rate of economic growth in 2012-2016. The method analysis used Location Quotient (LQ), Shift Share, and Klassen Typology. The results of the study reveal that the base sectors are agriculture, forestry and fishery, mining and excavation, procurement of electricity and gas, large and retail trade, and car and motorcycle repair; whereas, other sectors are included as non-base. The results of shift share method reveal that the competitive sectors are agriculture, forestry and fishery, government administration, mandatory defense and social security, educational services, transportation and warehousing, real estate, financial services, information and communication, health services and social activities, other services, provision of accommodation and food and beverage, company services, and procurement of electricity and gas. The result of Klassen typology indicates that there are two superior sectors, those are agriculture, forestry and fishery, and procurement of electricity and gas which are in quadrant I position.
\end{abstract}

Keywords: Gross Regional Domestic Product; Location Quatient (LQ); Shift Share; and Klassen Typology.

\begin{abstract}
Abstrak. Penelitian ini bertujuan untuk mengetahui sektor ekonomi basis, sektor-sektor ekonomi yang strategis dan potensial dikembangkan sebagai penunjang penerimaan daerah di Kabupaten Wajo. Penelitian ini merupakan penelitian deskriptif kuantitatif dengan menggunakan data Produk Domestik Regional Bruto dan laju pertumbuhan ekonomi pada tahun 2012-2016. Metode analisis yang digunakan adalah metode Location Quatient (LQ), Shift Share, dan Tipology Klassen. Hasil penelitian menunjukkan bahwa yang menjadi sektor basis adalah pertanian, kehutanan, dan perikanan, pertambangan dan penggalian, pengadaan listrik dan gas, perdagangan besar dan eceran, reparasi mobil dan sepeda motor sedangkan sektor lainnya termasuk non basis. Hasil metode Shift Share menunjukkan bahwa sektor yang kompetitif yaitu pertanian, kehutanan, dan perikanan, administrasi pemerintahan, pertahanan dan jaminan sosial wajib, jasa pendidikan, transportasi dan pergudangan, real estate, jasa keuangan, informasi dan komunikasi, jasa kesehatan dan kegiatan sosial, jasa lainnya, penyediaan akomodasi dan makan minum, jasa perusahaan, dan pengadaan listrik dan gas. Dari hasil Tipoloy Klassen menunjukkan dua sektor unggul yaitu pertanian, kehutanan, dan perikanan, dan pengadaan listrik dan gas berada pada posisi kuadran I.
\end{abstract}

Kata Kunci: Produk Domestik Regional Bruto; Location Quatient (LQ); Shift Share, dan Tipology Klassen. 


\section{PENDAHULUAN}

Salah satu indikator keberhasilan pelaksanaan pembangunan yang dapat dijadikan tolak ukur secara makro adalah pertumbuhan ekonomi. Pertumbuhan ini ditentukan oleh berbagai sector-sektor ekonomi. Penelitian ini dilakukan di Kabupaten Wajo karena berdasar dari daerah otonom yang memiliki kewenangan untuk menyelenggarakan pemerintahan dan pembangunan serta memberikan pelayanan kepada masyarakat, memiliki kewenangan untuk mengelola, merencanakan dan memanfaatkan potensi ekonomi secara optimal dalm menunjang pembangunan ekonomi daerah.

Pembangunan ekonomi merupkan suatu proses kerja antara pemerintah daerah dengan masyarakatnya dalam mengelola sumber daya yang ada dan membentuk suatu pola kemitraan antara pemerintah daerah dengan sektor swasta untuk menciptakan suatu lapangan kerja baru dan merangsang perkembangan kegiatan ekonomi dalam wilayah tersebut (Kuncoro, 2004).

Aspek pembangunan regional adalah pembangunan ekonomi yang bertujuan meningkatkan laju pertumbuhan ekonomi dan perubahan struktur ekonomi. Perubahan struktur ekonomi dapat berupa peralihan dari kegiatan pertanian ke non pertanian, dari industri ke jasa, perubahan dalam skala unit-unit produksi serta perubahan status kerja buruh karena itu konsep pembangunan regional sangat tepat bila didukung dengan teori pembangunan dan pertumbuhan ekonomi, teori pusat pertumbuhan dan pembangunan manusia.

Pertumbuhan ekonomi merupakan kenaikan output total suatu perekonomian atau dengan kata lain sebagai kenaikan GDP riil perkapita secara berkelanjutan dalam jangka panjang. Pertumbuhan ekonomi akan terjadi bila masyarakat mendapatkan lebih banyak sumber daya dan masyarakat menemukan cara penggunaan sumber daya yang tersedia secara lebih efisien. Untuk mengukur pertumbuhan ekonomi dengan menggunakan data produk domestik bruto (GDP), yang mengukur pendapatan total setiap orang dalam perekonomian (Mankiw, t.t. 2006:182).

Salah satu indikator dari keberhasilan pembangunan ekonomi adalah kemapuan sektor sektor ekonomi untuk memberikan kontribusi maksimal dalam perolehan pendapatan daerah. Untuk itu perli dilakukan pemetaan sektor-sektor ekonomi unggulan atau basis sehingga dapat menjadi motor penggerak perekonomian daerah.

Sektor unggulan merupakan sektor yang keberadaannya pada saat ini telah berperan dalam perkembangan perekonomian suatu wilayah. Kriteria unggulan daerah lebih ditekankan pada komoditas unggulan yang bisa menjadi motor penggerak pembangunan suatu daerah. Selain itu, komoditas unggulan daerah memiliki keterkaitan dengan daerah lain, demikian pula dengan pasar (konsumen) maupun pemasokan bahan baku (jika bahan baku di daerah sendiri tidak mencukupi atau tidak tersedia sama sekali). Komoditas unggulan memiliki status teknologi yang terus meningkat, terutama melalui inovasi teknologi. Nilawi tambah dari sektor dan komoditas unggulan memberi nilai tambah bagi perolehan Pendapatan Domestik Regional Bruto (PDRB).

Produk Domestik Regional Bruto adalah nilai tambah yang mampu diciptakan sebagai aktivitas ekonomi dalam suatu wilayah. Menurut Sukirno (2005) PDRB adalah nilai dari seluruh barang dan jasa yang diproduksi dalam waktu satu tahun disuatu wilayah tertentu tanpa membedakan kepemilikan faktor produksi, faktor produksi yang digunakan dalam proses produksi. PDRB merupakan salah satu cerminan kemajuan ekonomi suatu daerah.

Berdarkan uraian tersebut, maka tujuan dalam penelitian ini adalah untuk mengetahui sektor ekonomi basis, sektor-sektor ekonomi yang strategis dan potensial dikembangkan sebagai penunjang penerimaan daerah di Kabupaten Wajo.

\section{METODE}

Jenis penelitian ini adalah penelitian deskriptif kuantitatif dengan meneliti analisis sektor-sektor ekonomi terhadap penerimaan daerah Kabupaten Wajo. Adapun lokasi penelitian yaitu di wilayah Kabupaten Wajo, pengambilan data diperoleh dari instansi terkait yaitu Badan Pusat Statistik Kabupaten Wajo. Teknik pengumpulan data yaitu: (1) Observasi, peneliti mengadakan pengamatan langsung di lapangan terhadap objek yang diteliti. (2) Dokumentasi, Pengumpulan data dengan dokumentasi (pencatatan buku) untuk 
memperoleh data sekunder keadaan sektor-sektor ekonomi terhadap penerimaan daerah kabupaten Wajo, berupa data time series.

\section{Teknik analisis data yang digunakan adalah} sebagai berikut:

Analisis Location Quatient yaitu metode yang merupakan perbandingan antara pendapatan domestik regional bruto (PDRB) sektor ke-i terhadap penerimaan daerah, dengan persamaan sebagai berikut:

$L Q=\frac{\frac{x i}{\text { PDRB }}}{\text { PNB }}$

Di mana:

xi $=$ Nilai tambah sektor i di suatu daerah

PDRB $=$ Produk domestik regional bruto daerah tersebut

$\mathrm{Xi} \quad=$ Nilai tambah sektor i secara nasional

PNB = Produk nasional bruto atau GNP

Analisis Shift Share menurut (Adhitama dalam Tarigan, 2005:86) dapat membandingkan perbedaan laju pertumbuhan berbagai sektor (industri) di daerah (kabupaten) dengan wilayah yang lebih besar (provinsi). Jika nilai hasil analisis Shift Share berdasarkan nilai Cij bernilai positif maka sektor tersebut memiliki keunggulan kompetitif dan sebaliknya.

Analisis Tipology Klassen pendekatan sektoral pengklasifikasikan sektor ekonomi diperoleh dari hasil analisis Location Quatient dan analisis Shift Share.

\section{HASIL DAN PEMBAHASAN Pertumbuhan Ekonomi}

Pada tahun 2016, dari sisi pengeluaran pertumbuhan didorong oleh konsumsi rumah tangga, konsumsi lembaga non profit rumah tangga, konsumsi pemerintah, pembentukan modal tetap domestik bruto, ekspor barang dan jasa, dikurangi impor barang dan jasa, produk domestik bruto yang membaik. Dari sisi lapangan usaha, pertumbuhan ekonomi pada tahun 2016 tarjadi pada sebagian besar lapangan usaha.

Pertumbuhan ekonomi Kabupaten Wajo yang meningkat didorong oleh kinerja lapangan usaha Pertanian, kehutanan, dan perikanan; Pertambangan dan Penggalian; Pengadaan listrik dan gas; Perdagangan besar dan eceran, dan reparasi mobil dan sepeda motor. Secara keseluruhan, kinerja perekonomian Kabupaten Wajo tahun 2016 mencapai 4,98 persen. Sementara dari sisi pengeluaran, perekonomian Kabupaten Wajo ditopang oleh masih kuatnya konsumsi rumah tangga

\section{Keuangan Pemerintah}

Realisasi Anggaran Pendapatan Daerah Kabupaten Wajo tahun 2016 meningkat signifikan yaitu Rp 126 milyar dibandingkan dengan realisasi APBD tahun 2015. Dimana APBD tahun 2016 ditargetkan Rp 1,47 trilyun lebih dan sampai akhir tahun anggaran realisasi anggaran pendapatan sebesar $\mathrm{Rp} 1,40$ trilyun lebih atau 95,03 persen. Apabila dibandingkan tahun 2015, realisasi anggaran pendapatan daerah sebesar Rp 1,2 trilyun.

Dalam upaya mencapai pengelolaan pendapatan daerah yang lebih baik, maka perlu ditetapkan arah peningkatan pendapatan daerah. Arahan tersebut berfokus pada peningkatan dan optimalisasi pendapatan asli daerah utamanya pada penerimaan pajak daerah. Sementara belanja daerah tahun anggaran 2016, terealisasi sebesar Rp 1,4 trilyun lebih atau 91,67 persen dari anggaran sebesar $\mathrm{Rp} 1,5$ trilyun lebih. Kinerja pemerintah patut disyukuri bersama, karena realisasi APBD Wajo tahun 2016 meningkat sebesar Rp 148,7 milyar lebih atau 10,17 persen bila dibandingkan dengan tahun 2015 dari Rp 1,4 trilyun lebih meningkat menjadi Rp 1,6 trilyun lebih.

Realisasi pendapatan daerah daerah meningkat sebesar Rp 126 milyar lebih atau 9,85 persen, dari $\mathrm{Rp} 1,2$ trilyun lebih meningkat menjadi Rp 1,4 trilyun lebih. Pendapatan asli daerah juga mengalami peningkatan dari $\mathrm{Rp}$ 114,3 milyar lebih pada tahun 2015 menjadi Rp 117,7 milyar lebih pada tahun 2016 atau bertambah sebesar Rp 3,4 milyar lebih atau 3 persen.

Pendapatan asli daerah sebagai sumber penerimaan pajak merupakan indikator kekuatan dan kemandirian pembiayaan pembangunan daerah, juga merupakan komponen yang paling memungkinkan untuk dioptimalkan dan terus ditingkatkan penerimaannya. Namun demikian prinsip kehati-hatian dalam upaya peningkatan PAD merupakan hal utama agar masyarakat tidak merasa terbebani dalam pelaksanaan otonomi 
daerah serta meningkatkan kepercayaan masyarakat kepada pemerintah daerah. Untuk itu intensifikasi kegiatan perekonomian rakayat harus dilakukan secara proporsional dengan memperhatikan asas keadilan terhadap masyarakat.

Realisasi dana perimbangan keuangan mengalami peningkatan dari $\mathrm{Rp} 907,6$ milyar pada tahun 2015 menjadi sebesar Rp 1 trilyun pada tahun 2016 atau bertambah Rp 123,5 milyar atau meningkat 13,61 persen. Realisasi transfer pemerintah provinsi berupa bantuan keuangan dan pendapatan bagi hasil pajak juga mengalami peningkatan dari Rp 41 milyar lebih pada tahun 2015 menjadi Rp 59,8 milyar lebih pada tahun 2016 atau bertambah sebesar Rp 18 milyar lebih atau meningkat 43,35 persen.

Ranperda pertanggungjawaban pelaksanaan anggaran APBD tahun anggaran 2016 juga bersamaan dengan penyerahan 2 Ranperda lainnya yaitu, Ranperda perubahan atas Perda Kabupaten Wajo No. 9 tahun 2014 rencana pembangunan jangka menengah daerah Kabupaten Wajo tahun 2014-2019 dan Ranperda perubahan atas Perda Kabupaten Wajo No.39 tahun 2011 tentang penyelenggaraan administrasi kependudukan.

\section{Inflasi}

Inflasi di Kabupaten Wajo triwulan III 2016 sebesar 2,02 persen ( $\left.\mathrm{y}_{0} \mathrm{y}\right)$, lebih rendah dibandingkan triwulan II 2016 sebesar 2,67 persen $\left(\mathrm{y}_{\mathrm{o}} \mathrm{y}\right)$ sesuai dengan sasaran yang ditetapkan pemerintah. Komoditas utama di Kabupaten Wajo penyumbang inflasi terdiri dari ikan laying atau benggol, ikan bandeng atau bolu, telur ayam ras, emas perhiasan. Komoditas utama penyumbang deflasi yaitu beras, tomat sayur, ayam hidup, pisang, kol putih atau kubis.

Penurunan inflasi di akhir triwulan III 2016 terutama bersumber dari penurunan tekanan inflasi di kelompok core dan volatile food. Tekanan inflasi pada kelompok inti (core) pada triwulan III 2016 menurun cukup signifikan.
Secara umum, penurunan inflasi di kelompok ini masih berasal dari subkelompok makanan jadi dan sandang akibat kembali normalnya aktivitas masyarakat pasca bulan Ramadhan. Pada kelompok volatile food, konsumsi masyarakat yang terjaga menahan inflasi di triwulan III 2016.

Relatif stabilnya kelompok administered price didorong oleh masih terjaganya harga BBM khususnya bensin dan solar. Kebijakan pemerintah dalam menjaga harga BBM bersubsidi serta relatif stabilnya nilai tukar rupiah pada triwulan III 2016 turut menjaga inflasi kelompok administered price dalam kondisi deflasi. Meski demikian, meningkatnya permintaan angkutan baik angkutan antar kota dan angkutan dalam kota akibat arus mudik ebaran dan libur panjang pada bulan September menahan deflasi yang lebih dalam di kelompok ini. (Kajian Bank Indonesia, 2016)

\section{Penduduk dan Ketenagakerjaan}

Jumlah penduduk di Kabupaten Wajo pada tahun 2012 sebesar 389.284 jiwa, tahun 2013 sebesar 390.603 jiwa, tahun 2014 sebesar 391.980 jiwa, tahun 2015 sebesar 393.218 jiwa, tahun 2016 sebesar 394.495 jiwa. Jumlah angkatan kerja sebesar 177.301 jiwa. Dari 177.301 jiwa angkatan kerja, yang bekerja sebesar 96,94 persen dan Tingkat Pengangguran Terbuka (TPT) menunjukkan penurunan sekitar 5.000 jiwa atau presentasi 3,06 persen lebih rendah dibandingkan periode yang sama tahun sebelumnya. Sementara sektor paling banyak menyerap tenaga kerja adalah pertanian. Pertumbuhan ekonomi kategori pertanian naik tapi tidak menyerap tenaga kerja dengan maksimal karena semakin berkembangnya teknologi pertanian.

\section{Analisis Location Quatient (LQ)}

Hasil analisis LQ Kabupaten Wajo tahun 2012-2016 dapat dilihat pada berikut:

Tabel 1. Hasil Perhitungan Indeks Location Quotient (LQ) Kabupaten Wajo Tahun 2012-2016

\begin{tabular}{lllllllll}
\hline Lapangan Usaha & LQ & LQ & LQ & LQ & LQ & Jumlah & $\begin{array}{l}\text { Rata- } \\
\text { rata LQ }\end{array}$ & Ket \\
& $\mathbf{2 0 1 2}$ & $\mathbf{2 0 1 3}$ & $\mathbf{2 0 1 4}$ & $\mathbf{2 0 1 5}$ & $\mathbf{2 0 1 6}$ & LQ & Basis \\
\hline $\begin{array}{l}\text { Pertanian, Kehutanan, dan } \\
\text { Perikanan }\end{array}$ & 1,42 & 1,45 & 1,42 & 1,41 & 1,46 & 7,16 & 1,43 & Basis \\
\hline
\end{tabular}


Bunaya, Chalid Imran Musa, Rahmatullah, Analisis Sektor-Sektor Ekonomi...| 55

\begin{tabular}{|c|c|c|c|c|c|c|c|c|}
\hline $\begin{array}{l}\text { Pertambangan dan } \\
\text { Penggalian }\end{array}$ & 3,77 & 3,47 & 3,55 & 3,62 & 3,44 & 17,85 & 3,57 & Basis \\
\hline Industri Pengolahan & 0,31 & 0,26 & 0,25 & 0,25 & 0,25 & 1,32 & 0,26 & Non Basis \\
\hline $\begin{array}{l}\text { Pengadaan Listrik dan } \\
\text { Gas }\end{array}$ & 1,20 & 1,14 & 1,02 & 1,15 & 1,12 & 5,63 & 1,13 & Basis \\
\hline $\begin{array}{l}\text { Pengadaan Air, } \\
\text { Pengelolaan Sampah, } \\
\text { Limbah, dan Daur Ulang }\end{array}$ & 0,33 & 0,29 & 0,29 & 0,29 & 0,29 & 1,49 & 0,30 & Non Basis \\
\hline Konstruksi & 0,80 & 0,74 & 0,72 & 0,72 & 0,73 & 3,71 & 0,74 & Non Basis \\
\hline $\begin{array}{l}\text { Perdagangan Besar dan } \\
\text { Eceran, dan Reparasi } \\
\text { Mobil dan Sepeda Motor }\end{array}$ & 1,20 & 1,09 & 1,08 & 1,07 & 1,09 & 5,53 & 1,11 & Basis \\
\hline $\begin{array}{l}\text { Transportasi dan } \\
\text { Pergudangan }\end{array}$ & 0,91 & 0,85 & 0,89 & 0,88 & 0,88 & 4,41 & 0,88 & NonBasis \\
\hline $\begin{array}{l}\text { Penyediaan Akomodasi } \\
\text { dan Makan Minum }\end{array}$ & 0,26 & 0,24 & 0,24 & 0,24 & 0,25 & 1,23 & 0,25 & Non Basis \\
\hline $\begin{array}{l}\text { Informasi dan } \\
\text { Komunikasi }\end{array}$ & 0,31 & 0,28 & 0,27 & 0,28 & 0,29 & 1,43 & 0,29 & Non Basis \\
\hline Jasa Keuangan & 0,72 & 0,69 & 0,67 & 0,67 & 0,70 & 3,45 & 0,69 & Non Basis \\
\hline Real Estate & 0,84 & 0,86 & 0,86 & 0,87 & 0,89 & 4,32 & 0,86 & Non Basis \\
\hline Jasa Perusahaan & 0,25 & 0,26 & 0,26 & 0,26 & 0,26 & 1,29 & 0,26 & Non Basis \\
\hline $\begin{array}{l}\text { Administrasi } \\
\text { Pemerintahan, Pertahanan } \\
\text { dan Jaminan Sosial Wajib }\end{array}$ & 0,89 & 0,88 & 0,86 & 0,86 & 0,88 & 4,37 & 0,87 & Non Basis \\
\hline Jasa Pendidikan & 0,57 & 0,62 & 0,61 & 0,61 & 0,63 & 3,04 & 0,61 & Non Basis \\
\hline $\begin{array}{l}\text { Jasa Kesehatan dan } \\
\text { Kegiatan Sosial }\end{array}$ & 0,64 & 0,65 & 0,64 & 0,63 & 0,64 & 3,20 & 0,64 & Non Basis \\
\hline Jasa Lainnya & 0,32 & 0,32 & 0,31 & 0,30 & 0,31 & 1,56 & 0,31 & Non Basis \\
\hline
\end{tabular}

Sumber: Hasil Olah Data, 2018.

Berdasarkan tabel menunjukkan bahwa di Kabupaten Wajo yang termasuk sektor basis yaitu Pertanian, kehutanan, dan perikanan, Pertambangan dan penggalian, Pengadaan listrik dan gas, dan Perdagangan Besar dan Eceran, dan Reparasi mobil dan Sepeda motor. Hal ini berarti bahwa sektor tersebut memiliki kekuatan ekonomi yang cukup baik dan sangat berpengaruh terhadap peningkatan pertumbuhan ekonomi. Sektor ekonomi ini mampu memenuhi kebutuhan di daerahnya dan bahkan berpotensi ekspor. Sedangkan keenam sektor lainnya termasuk sektor non basis. Walaupun sektor basis merupakan sektor yang potensial untuk dikembangkan karena mampu memacu pertumbuhan ekonomi di Kabupaten Wajo, tetapi sebaiknya sektor non basis tidak boleh diabaikan, karena sektor ini juga harus diusahakan untuk dikembangkan agar menjadi sektor basis baru. 
Bunaya, Chalid Imran Musa, Rahmatullah, Analisis Sektor-Sektor Ekonomi...| 56

\section{Analisis Shift Share}

Tabel 2. Hasil Analisis Komponen Shift Share Kabupaten Wajo Periode 2012-2016

\begin{tabular}{lllll}
\hline Lapangan Usaha & \multicolumn{4}{c}{ Komponen } \\
\cline { 2 - 5 } & $\mathbf{N}_{\mathbf{i j}}$ & $\mathbf{M}_{\mathbf{i j}}$ & $\mathbf{C}_{\mathbf{i j}}$ & $\mathbf{D}_{\mathbf{i j}}$ \\
Pertanian, Kehutanan, dan & $888.408,60$ & $-16.339,70$ & $92.492,85$ & $964.561,74$ \\
Perikanan & & & & \\
Pertambangan dan Penggalian & $635.296,99$ & $-102.896,01$ & $-110.105,29$ & $422.295,69$ \\
Industri Pengolahan & $104.448,22$ & $15.626,90$ & $-20.718,03$ & $99.357,10$ \\
Pengadaan Listrik dan Gas & $2.857,78$ & 558,01 & 218,16 & $3.633,95$ \\
Pengadaan Air, Pengelolaan & $1.203,06$ & $-686,97$ & $-184,43$ & 331,66 \\
Sampah, Limbah, dan Daur Ulang & & & & \\
Konstruksi & $243.036,22$ & $24.278,78$ & $-4.602,35$ & $262.712,65$ \\
Perdagangan Besar dan Eceran, & $442.395,37$ & $49.154,32$ & $-48.191,73$ & $443.357,96$ \\
dan Reparasi mobil dan Sepeda & & & & \\
Motor & & & & \\
Transportasi dan Pergudangan & $92.256,15$ & $-24.262,65$ & $25.281,22$ & $93.274,72$ \\
Penyediaan Akomodasi dan Makan & $9.095,72$ & $-142,11$ & $1.900,70$ & $10.854,31$ \\
Minum & & & & \\
Informasi dan Komunikasi & $47.950,25$ & $11.959,90$ & $4.729,91$ & $64.640,06$ \\
Jasa Keuangan & $66.982,78$ & $16.244,89$ & $7.831,76$ & $91.059,43$ \\
Real Estate & $82.584,35$ & $4.525,82$ & $35.033,49$ & $122.143,65$ \\
Jasa Perusahaan & $2.993,83$ & $-202,26$ & $1.027,15$ & $3.818,72$ \\
Administrasi Pemerintahan, & $120.160,29$ & $-74.785,59$ & $12.835,52$ & $58.210,22$ \\
Pertahanan dan Jaminan Sosial & & & & \\
Wajib & & & & \\
Jasa Pendidikan & $93.033,26$ & $-37.460,09$ & $48.883,79$ & $104.456,96$ \\
Jasa Kesehatan dan Kegiatan Sosial & $33.095,75$ & $8.950,28$ & $353.524,80$ & $395.570,83$ \\
Jasa Lainnya & $11.341,23$ & $1.848,93$ & $114.820,08$ & $128.010,24$ \\
\hline Total PDRB & $\mathbf{2 . 8 7 7 . 1 3 9 , 8 4}$ & $\mathbf{- 1 2 3 . 6 2 7 , 5 6}$ & $\mathbf{5 1 4 . 7 7 7 , 6 0}$ & $\mathbf{3 . 2 6 8 . 2 8 9 , 8 9}$ \\
\hline Sumberyyyyy
\end{tabular}

Sumber: Hasil Olah Data, 2018.

Berdasarkan analisis Shift share, sektor yang mengalami peningkatan pertumbuhan riil di Kabupaten Wajo yaitu Peningkatan terbesar terjadi pada sektor pertanian, kehutanan, dan perikanan, sektor perdagangan besar dan eceran, dan reparasi mobil dan sepeda motor, dan sektor pertambangan dan penggalian dengan nilai pertumbuhan rill sektor masing-masing 964.561,74 juta rupiah, 443.357,96 juta rupiah, dan 422.295,69 juta rupiah.

Peningkatan pertumbuhan nilai PDRB sektor perekonomian dipengaruhi oleh beberapa faktor, yaitu diantaranya pengaruh pertumbuhan PDRB sektor Perekonomian Provinsi Sulawesi Selatan (Nij). Pertumbuhan sektor pertanian, kehutanan, dan perikanan di Kabupaten Wajo dipengaruhi oleh pertumbuhan sektor pertanian, kehutanan, dan perikanan Provinsi Sulawesi Selatan yaitu sebesar 888.408,60 juta rupiah. Pengaruh pertumbuhan PDRB sektor pertambangan dan penggalian di provinsi Sulawesi Selatan sebesar 635.296,99 juta rupiah. Pengaruh pertumbuhan PDRB sektor perdagangan besar dan eceran, dan reparasi mobil dan sepeda motor di Provinsi Sulawesi Selatan sebesar 442.395,37 juta rupiah, sektor konstruksi sebesar 243.036,22 juta rupiah, sektor administrasi pemerintahan, pertahanan dan jaminan sosial wajib sebesar 120.160,29 juta rupiah, sektor industri pengolahan sebesar 104.448,22 juta rupiah, sektor jasa pendidikan sebesar 93.033,26 juta rupiah, sektor transportasi dan pergudangan sebesar 92.256,15 juta rupiah, sektor real estate sebesar $82.584,35$ juta rupiah, 
sektor jasa keuangan sebesar 66.982,78 juta rupiah, sektor informasi dan komunikasi sebesar 47.950,25 juta rupiah, sektor jasa kesehatan dan kegiatan sosial sebesar 33.095,75 juta rupiah, sektor jasa lainnya sebesar 11.341,23 juta rupiah, sektor penyediaan akomodasi dan makan minum sebesar 9.095,72 juta rupiah, sektor jasa perusahaan sebesar 2.993,83 juta rupiah, sektor pengadaan listrik dan gas sebesar 2.857,78 juta rupiah, dan sektor pengadaan air, pengelolaan sampah, limbah, dan daur ulang sebesar 1.203,06 juta rupiah.

Pengaruh komponen bauran industri (Mij) yang bernilai positif menunjukkan bahwa laju pertumbuhan Sektor perekonomian di Kabupaten Wajo mengalami peningkatan. Sektor yang mengalami pertumbuhan adalah sektor perdagangan besar dan eceran, dan reparasi mobil dan sepeda motor, sektor konstruksi, sektor industri pengolahan, sektor real estate, sektor jasa keuangan, sektor informasi dan komunikasi, sektor jasa kesehatan dan kegiatan sosial, sektor jasa lainnya, dan sektor pengadaan listrik dan gas. Sektor perdagangan besar dan eceran, dan reparasi mobil dan sepeda motor merupakan sektor yang memiliki pertumbuhan tertinggi yaitu sebesar 49.154,32 juta rupiah. Sektor perekonomian di Kabupaten Wajo yang mengalami penurunan laju pertumbuhan nilai PDRB paling besar adalah Sektor pertambangan dan penggalian dengan nilai $-102.896,01$ juta rupiah.

Dilihat dari nilai Cij (komponen keunggulan kompetitif), diketahui bahwa komoditas yang memiliki keunggulan kompetitif adalah sektor pertanian, kehutanan, dan perikanan, sektor administrasi pemerintahan, pertahanan dan jaminan sosial wajib, sektor jasa pendidikan, sektor transportasi dan pergudangan, sektor real estate, sektor jasa keuangan, sektor informasi dan komunikasi, sektor jasa kesehatan dan kegiatan sosial, sektor jasa lainnya, sektor penyediaan akomodasi dan makan minum, sektor jasa perusahaan, dan sektor pengadaan listrik dan gas. Sektor jasa kesehatan dan kegiatan sosial merupakan sektor dengan tingkat keunggulan kompetitif paling tinggi dibandingkan komoditas lainnya yaitu sebesar 353.524,80 juta rupiah. Sektor yang tidak memiliki keunggulan kompetitif adalah sektor pertambangan dan penggalian dengan nilai sebesar $-110.105,29$ juta rupiah.

Analisis Tipology Klassen

Klasifikasi sektor perekonomian di Kabupaten Wajo selama periode pengamatan tahun 2012-2016 menunjukkan bahwa terdapat dua sektor yang masuk dalam klasifikasi sektor unggul yaitu sektor pertanian, kehutanan, dan perikanan dan sektor pengadaan listrik dan gas.

Tabel 3. Hasil Rekapitulasi Tipology Klassen Sektor Perekonomian di Kabupaten Wajo Tahun 2012-2016

\section{$\begin{array}{llll}\text { Lapangan Usaha } & \text { LQ } & \text { Cij } & \text { Kuadran }\end{array}$}

\begin{tabular}{llll}
\hline Pertanian, kehutanan, dan perikanan & $1,43$ (LQ $>1)$ & $92.492,85$ (positif) & 1 \\
Pertambangan dan penggalian & $3,57(\mathrm{LQ}>1)$ & $-110.105,29$ (negatif) & 2 \\
Industri Pengolahan & $0,26(\mathrm{LQ}<1)$ & $-20.718,03$ (negatif) & 4 \\
Pengadaan listrik dan gas & $1,13$ (LQ $>1)$ & 218,16 (positif) & 1 \\
Pengadaan air, Pengelolaan sampah, & $0,30(\mathrm{LQ}<1)$ & $-184,43$ (negatif) & 4 \\
limbah, dan daur ulang & $0,74(\mathrm{LQ}<1)$ & $-4.602,35$ (negatif) & 4 \\
Konstruksi & $1,11$ (LQ $>1)$ & $-48.191,73$ (negatif) & 2 \\
Perdagangan Besar dan Eceran, dan & $0,88(\mathrm{LQ}<1)$ & $25.281,22$ (positif) & 3 \\
Reparasi mobil dan Sepeda Motor & $0,25(\mathrm{LQ}<1)$ & $1.900,70$ (positif) & 3 \\
Transportasi dan Pergudangan & $0,29(\mathrm{LQ}<1)$ & $4.729,91$ (positif) & 3 \\
Penyediaan Akomodasi dan Makan & $0,69$ (LQ $<1)$ & $7.831,76$ (positif) & 3 \\
Minum & $0,86$ (LQ $<1)$ & $35.033,49$ (positif) & 3 \\
Informasi dan Komunikasi & $0,26$ (LQ $<1)$ & $1.027,15$ (positif) & 3 \\
Jasa Keuangan &
\end{tabular}


Bunaya, Chalid Imran Musa, Rahmatullah, Analisis Sektor-Sektor Ekonomi...| 58

Administrasi Pemerintahan,

Pertahanan dan Jaminan Sosial Wajib

$0,87(\mathrm{LQ}<1)$
$0,61(\mathrm{LQ}<1)$
$0,64(\mathrm{LQ}<1)$
$0,31(\mathrm{LQ}<1)$

$12.835,52$ (positif)

3

Jasa Pendidikan

Jasa Kesehatan dan Kegiatan Sosial

$48.883,79$ (positif)

$353.524,80$ (positif)

$114.820,08$ (positif)

Sumber: Hasil Olah Data, 2018.

Sektor yang tergolong dalam kategori sektor potensial adalah sektor pertambangan dan penggalian, sektor perdagangan besar dan eceran, dan reparasi mobil dan sepeda motor, sektor transportasi dan pergudangan, sektor penyediaan akomodasi dan makan minum, sektor informasi dan komunikasi,sektor jasa keuangan, sektor real estate, sektor jasa perusahaan, sektor administrasi pemerintahan, pertahanan dan jaminan sosial wajib, sektor jasa pendidikan, sektor jasa kesehatan dan kegiatan sosial, dan sektor jasa lainnya, dan tiga sektor yang tergolong dalam klasifikasi sektor terbelakang yaitu sektor industri pengolahan, sektor pengadaan air, pengelolaan sampah, limbah, dan daur ulang, dan sektor konstruksi. Sedangkan, sektor pertambangan dan penggalian dan sektor perdagangan besar dan eceran, dan reparasi mobil dan sepeda motor merupakan sektor yang memiliki pertumbuhan tinggi, namun, memiliki kontribusi yang rendah. Pertumbuhan tinggi ini sejalan dengan program pemerintah daerah Kabupaten Wajo. Namun pertumbuhan yang tinggi ini tidak sejalan dengan kontribusi yang diberikan sektor pertambangan dan penggalian terhadap perekonomian Kabupaten Wajo, hal ini disebabkan nilai ratarata kontribusi kedua sektor lebih rendah sektor penyediaan akomodasi dan makan minum, sektor jasa perusahaan, dan sektor pengadaan listrik dan gas, sedangkan sektor lainnya memiliki nilai rata-rata negatif.

3. Berdasarkan anlisis tipology klassen, sektor yang diklasifikasikan sebagai sektor unggulan yaitu sektor pertanian, kehutanan, dan perikanan, dan sektor pengadaan listrik dan gas sedangkan sektor lainnya terdiri dari dua belas sektor yang masuk dalam kategori potensial dan dua sektor lainnya tergolong sektor yang terbelakang. dibandingkan nilai rata-rata kontribusi sektor yang sama di tingkat yang lebih luas (Sulawesi Selatan).

\section{SIMPULAN DAN SARAN \\ Simpulan}

Berdasarkan hasil analisis dan pembahasan, maka dapat disimpulkan:

1. Berdasarkan analisis LQ, yang termasuk sektor basis yaitu Pertanian, kehutanan, dan perikanan, Pertambangan dan penggalian, Pengadaan listrik dan gas, dan Perdagangan besar dan eceran, dan reparasi mobil dan sepeda motor. Sedangkan sektor lainnya termasuk sektor non basis.

2. Berdasarkan analisis shift share, sektor yang memiliki keunggulan kompetitif adalah sektor pertanian, kehutanan, dan perikanan, sektor administrasi pemerintahan, pertahanan dan jaminan sosial wajib, sektor jasa pendidikan, sektor transportasi dan pergudangan, sektor real estate, sektor jasa keuangan, sektor informasi dan komunikasi, sektor jasa kesehatan dan kegiatan sosial, sektor jasa lainnya.

\section{Saran}

Sektor basis merupakan sektor yang sangat potensial untuk dikembangkan dalam pembangunan ekonomi Kabupaten Wajo dan dapat menjadi penarik bagi sektor-sektor yang lain (non basis) untuk dapat dikembangkan. Untuk itu perlu adanya perhatian yang dituangkan dalam bentuk regulasi agar pembangunan sektor non basis juga dapat dilakukan secara maksmimal, sehingga dapat menjadi sektor unggulan baru dalam pembagunan ekonomi di Kabupaten Wajo. 


\section{DAFTAR RUJUKAN}

Adhitama, R. 2012. Pengembangan SektorSektor Ekonomi di Tiap Kecamatan di Kabupaten Magelang. Economics Development Analysis Journal 1 (2).

Badan Pusat Statistik (BPS). 2018. PDRB Provinsi Sulawesi Selatan. BPS Pusat Makassar.

.2018. Wajo Dalam Angka. BPS Provinsi Sulawesi Selatan.

Baransano, M. A., Putri, E. I. K., Achsani, N. A., \& Kolopaking, L. M. 2016. Analysis of Factors Affecting Regional Development Disparity in the Province of West Papua. Journal of Economics and Development Studies, 4(2), 115128.

Deliarnov. 2014. Perkembangan Pemikiran Ekonomi Edisi Ketiga. Jakarta: Rajawali Pers.

Eachern. 2000. Ekonomi Makro (Pendekatan Kontemporer). Jakarta: Salemba Empat.

Ebiringa, O., \& Yadirichukwu, E. 2012. Analysis of tax formation and impact on economic growth in Nigeria. International Journal of Accounting and Financial Reporting, 2(2), 367.

Jhingan. 2016. Ekonomi Pembangunan dan Perencanaan. Jakarta: PT. Raja Grafindo Persada.
Kantor Bappeda Kabupaten Wajo. 2019. Profil Kabupaten Wajo. Http: bappeda.wajokab.go.id. Diakses, 1 Mei 2019.

Kantor Perwakilan Bank Indonesia Provinsi Sulawesi Selatan. 2016. Kajian Ekonomi dan Keuangan Regional Provinsi Sulawesi Selatan November 2016 (Terbit Setiap Triwulan). Http: www.bi.go.id/web/id/Publikasi/. Diakses, 2 Mei 2019.

Kuncoro, M. 2004. Otonomi dan Pembangunan Daerah: Reformasi, Perencanaan. Strategi, dan Peluang. Jakarta: Erlangga.

Mankiw, N. (t.t.). Gregory .2006. Teori Makro Ekonomi, Edisi Kelima (terjemahan). Jakarta: Erlangga.

Rachim, A., \& Abd, H. 2015. Analyzing Local Revenue in Local Otonomy Implementation towards Self-Reliance of Samarinda Municipality. International Journal of Business Management \& Economic Research, 6(6).

Tarigan, R. 2014. Ekonomi Regional Teori dan Aplikasi, Edisi Revisi, Cetakan Ketujuh, Maret 2014. Jakarta: PT. Bumi Aksara, Jakarta.

Todaro, M. P., \& Smith, S. C. 2006. Pembangunan Ekonomi edisi kesembilan. Jakarta: Erlangga. 